2018-07-02

\title{
Why did Italy contribute to UNIFIL II? An analytical eclectic analysis
}

\author{
Cladi, Lorenzo
}

http://hdl.handle.net/10026.1/11838

10.1017/ipo.2018.10

Italian Political Science Review/Rivista Italiana di Scienza Politica

Societa Editrice il Mulino

All content in PEARL is protected by copyright law. Author manuscripts are made available in accordance with publisher policies. Please cite only the published version using the details provided on the item record or document. In the absence of an open licence (e.g. Creative Commons), permissions for further reuse of content should be sought from the publisher or author. 
Why did Italy contribute to UNIFIL II? An analytical eclectic analysis LORENZO CLADI $^{1 *}$ AND ANDREA LOCATELLI ${ }^{2}$

${ }^{1}$ School of Law, Criminology and Government, University of Plymouth (UK)

${ }^{2}$ Dipartimento di Scienze Politiche, Università Cattolica del Sacro Cuore, Milan (Italy)

This is an Accepted Manuscript of an article published by Cambridge University Press in Italian Political Science Review/Rivista Italiana di Scienza Politica.

A link to the full published version can be found here:

https://www.cambridge.org/core/journals/italian-political-science-

review-rivista-italiana-di-scienza-politica/article/why-did-italy-

contribute-to-unifil-ii-an-analytical-eclecticanalysis/7C8706C8F164990694A58C894C2E06F3

\begin{abstract}
After the 2006 war between Israel and Hezbollah, the UN launched the peacekeeping operation UNIFIL II. Italy embarked on the demanding task of taking responsibility for leading the mission. We present a model of military
\end{abstract}

*E-mail: Lorenzo.cladi@plymouth.ac.uk 
intervention in multilateral operations that aims at highlighting the mechanisms at stake. In so doing, we argue that an analytical eclectic approach offers a novel explanation of Italy's behaviour. We explain the drivers of Italy's intervention in Lebanon in two ways. Firstly, we analyse Italy's actions at the outset of the crisis. Secondly, we provide an account of the parliamentary debate that took place in both chambers of the Italian Parliament between July and October 2006.

Keywords: Italy, Lebanon, UNIFIL II, Analytical eclecticism 


\section{Introduction}

In the summer of 2006, Italy took an active role in launching and sustaining UNIFIL II, the UN operation in Lebanon. Italy's decision to embark on the demanding task of participating in the mission defies mono-causal theoretical explanations. In fact, a number of drivers, which link in turn to different theories, may be used to account for this behaviour. Yet, none of these rules out the others. As we will see in the next few pages, one likely candidate as a driver is prestige (i.e. Italy sought to increase its status within the international system). Alternatively, the decision to intervene could have been taken because of a particular interest of the government in power at that given moment in time. Furthermore, a third driver could be found in humanitarian concern. At first sight, the drivers, which we have identified, would provide competing theoretical explanations of Italy's decision to contribute to UNIFIL II. However, they are not mutually exclusive. In this article, we argue that an analytical eclectic approach, i.e. one that integrates the above-mentioned drivers and that specifies how they interact, holds more explanatory power than mono-causal explanations.

In doing so, we aim for a twofold contribution to the literature. Firstly, we are interested in contributing to the debate on International Relations (IR) theoretically based explanations of Italian foreign policy. This literature has considerably expanded in recent 
years and it has mainly focused on single theoretical explanations (Cladi and Webber 2011; Ratti 2012; Olmastroni 2014). More recently, other scholars have begun to consider different drivers to provide a more nuanced account of Italian foreign policy (Ceccorulli and Coticchia 2015; 2017; Tercovich 2016; Carati and Locatelli 2017). However, an attempt to use analytical eclecticism is missing. ${ }^{1}$ We address this gap by presenting a model that sheds lights on the interaction among the different drivers. Secondly, we contribute to the wider literature on the study of the drivers of a middle power's foreign policy. While the field of foreign policy analysis (FPA) has tended to focus on the drivers of a country's foreign policy (Thies and Breuning 2012), there has been a propensity to focus on great powers such as the US and the UK (Freedman 1976; Marsh 2008). These states have tended to project their military power globally. Explanations of foreign policies of states that have traditionally been more reluctant to use force, such as Germany, have also found space in the literature (Kaarbo 1996; Harnish 2001). However, the case of a middle power such as Italy, being willing to contribute to a costly and risky military mission short of a clear return, as a great power would, is underdeveloped. This is quite regrettable, as Italy ended up being a major contributor to multilateral military operations in the past quarter century, ranking seventh among major contributors to UN peacekeeping operations (Carati and Locatelli 2017).

\footnotetext{
${ }^{1}$ The lack of 'theoretical cumulation' has also been recently noted by Pierangelo Isernia and Francesca Longo $(2017,113)$ in their up to date map of theoretical approaches to the study of Italian foreign policy.
} 
In order to advance the argument presented above, the article is organised as follows. The first section presents the eclectic model that addresses Italy's decision to commit military forces to UNIFIL II. The second section provides an empirical account of Italy's decision to intervene in Lebanon, with a particular focus on the resulting parliamentary debate, to assess whether the drivers discussed had a sway over the political process. Finally, the concluding section wraps up the argument and discusses future avenues of research.

\section{An eclectic model of military intervention in multilateral operations}

This article offers a novel eclectic model of military intervention in multilateral operations. We argue that this model can explain Italy's decision to commit military forces to the UNIFIL II multilateral operation to bring to an end the conflict between Israel and Hezbollah in 2006. We begin this section by outlining each of the factors involved in the model and discuss how they led to Italy's intervention. The article's eclectic model of military intervention in multilateral operations features three causal factors: prestige, governmental interest and humanitarian concern. Coherently with the 
eclectic approach (Sil and Katzenstein 2010), the model proposes that these factors play their own role in the causal process but also that each factor affects other causal factors.

\section{Causal factors}

The first factor, prestige, has been discussed at greater length within the classical realist paradigm (see, among others, Morgenthau 1985; Gilpin 1981). However, this concept (or its close relative status) has recently attracted a good deal of interest in the field, so departing from its realist ancestry (Larson and Shevchenko 2010; Volgy et al. 2011; Wood 2013; Renshon 2017). In particular, the issue has found fertile ground within the constructivist approach.

For instance, authors like Larson and Shevchenko (2010) have analysed status seeking as a strategy of social mobility: in a nutshell, states willing to increase their own status - if they share common values and do not perceive high barriers to the higher ranks of prestige - would likely avoid competition with great powers, opting instead for a strategy of imitation. On a similar vein, Volgy et al. (2010) have discussed different types of foreign policy behaviour depending on the relationship between rank and role (for an early treatment see Santoro 1991). In particular, Italy would fit the category of statusinconsistent overachiever - i.e. a country whose international standing exceeds its 
capabilities. Therefore, following this growing body of literature, we can assume that the decision to intervene in Lebanon was driven by considerations of status or prestige.

Beyond theoretical considerations, resorting to prestige as an explanatory factor is also consistent with the literature on Italian foreign policy. In fact, after the end of the Cold War, a broad consensus emerged on the belief that military engagement would contribute to an increase in the country's prestige in international relations (Davidson 2009; Carati and Locatelli 2015; Romero 2016: 8). On the other hand, as noted by James Walston (2007), despite being successful in gaining a reputation as a middle power (see also Andreatta 2001), Italy could not fully turn it into influence due to its domestic weakness (Andreatta 2008) - with the result of feeding a perception of unreliability. The need to compensate for this reputation has been seen by some scholars as key to the two main pillars of the Italian diplomacy: the dual relationship with the US and Europe (Romano 2009; Croci 2007).

In light of these considerations, it is possible to argue that Italy sought to pursue prestige to obtain recognition of its status in the international stage. Two reasons support this argument's claim: firstly, given its weakness in military capabilities, Italy's commitment to multilateral peace operations is a rational strategy to demonstrate reliability as a member of the international community (Carati and Locatelli 2015). On the other hand, 
as impediments to multilateral action are many - the collective action problem being the most notable - the active role played by Italy in the context of the crisis can also be understood as an attempt to make multilateralism work - i.e. costly signalling to prove the Italian commitment to multilateral institutions.

Yet, focusing solely on prestige would be a limit to our model's explanatory power. A middle power such as Italy would not be able to intervene solely because of prestige. This leads us to the second causal factor: governmental interest. To address this, we turn to the liberal school. The liberal intergovernmental approach asserts that governmental interest drives a state's intervention. Assuming that states use international institutions as a vehicle to assert their interests, where those interests come from requires investigation. For liberalism, interests are formulated by the governments in power and should be representative of the societies they represent. The logic of liberalism is therefore consequential rather than appropriate; governments are 'motivated by the consequences that their actions are expected to bring about' (Pohl, van Willigen, and Van Vonno 2016, 67). International institutions are the vehicles through which states pursue their interests. However, as institutions also exert influence upon states' behaviour, states struggle to utilise international institutions for their own benefit (Vanhoonacker, Dijkstra, and Maurer 2010). In this scenario, domestic politics is not an independent variable determining how the interest is framed before it is pursued at an institutional level. 
Governments may pursue a foreign policy course not in order to maximise the country's power, but to stay in power.

In this context, Italy's decision to contribute to UNIFIL II is dependent on the governmental interest of Romano Prodi's government. When the conflict between Israel and Hezbollah started, the centre-left government had been in power for two months. The contribution to UNIFIL II represented a timely opportunity for the government to live up to the expectations, which were raised during the electoral campaign. In fact, one of Prodi's main themes during the campaign was to revamp the European Union's international role and multilateral institutions (UN in particular). In this regard, the war in Lebanon provided a double opportunity: on one hand to intervene through the United Nations; on the other, to mark a difference with the previous (purportedly calamitous) experience in Iraq led by the Berlusconi government.

Our model's explanatory power relies on a third causal factor, which refers to the way in which Italy justified its choice of intervening in Lebanon: humanitarian concern. In line with our analytical eclectic approach, we argue that an ideational factor such as humanitarian concern is not enough to influence a country's decision to get involved in a conflict. Jeffrey Legro's remark that 'something more than ideas has to be involved in major foreign policy transformations' $(2005$, p. 13) is helpful in this regard. Still, the 
justification for intervention (Sørensen 2008) that Italy used was to alleviate humanitarian distress. Such a norm does not shape the interest per se but, as Diana Panke and Thomas Risse have argued, it can 'influence strategic choices and enable, sanction or prevent certain actions' $(2007,93)$. Martha Finnemore makes a similar point in arguing that the 'normative context [...] shapes conceptions of interest' (1996, 154). Governments are driven by the logic of appropriateness in responding to societal pressures for action (Robinson 2001).

In the case of the 2006 conflict between Israel and Hezbollah, the EU roundly condemned Israel's disproportionate use of force and thus created the normative context for the deployment of a peacekeeping force in Southern Lebanon (Smith 2006). The UN legitimised Israel's war with Hezbollah but condemned, along with European and Arab states, Israel's 'unnecessarily disproportionate violence that had caused a human disaster' (Makdisi 2011, 13). Following this logic, the greater the humanitarian concern, the greater the chance of success in assembling the multilateral coalition for the intervention. In the same vein, the constructivist perspective can also shed light on the way Italy decided to intervene - in other words, the humanitarian framing of the mission. Indeed, when UN resolution 1701 called for a strengthened UNIFIL force, the nature of the mission was far from clear: whether Hezbollah would surrender without resistance, and Israel forces would withdraw or not, was just a matter of speculation. In other words, when the decision 
to intervene was taken, the operational goals, rules of engagement and eventually the very same level of violence that Italian soldiers were about to experience remained uncertain.

This is where strategic culture kicks in: borrowing (among many) from Johnston's seminal contribution, we can define the concept as 'an integrated set of symbols [...] that act to establish pervasive and long-standing grand strategic preferences by formulating concepts of the role efficacy of military force' (Johnston 1995, 36). As argued by many authors, one of the main traits of the Italian strategic culture is the framing of military interventions as peace and humanitarian operations (Coticchia and Giacomello, 2008; Ignazi, Giacomello, and Coticchia 2011; Pirani 2010). In the context of the humanitarian framing, even the Partito della Rifondazione Comunista (PRC), significantly departed from its radical anti-war positions and backed the intervention in Lebanon (Hudson 2012, 99).

The eclectic model applied to Italy's involvement in Lebanon

We contend that in the case under scrutiny, all the causal factors played a role and an eclectic model is necessary to observe the mechanisms at play (see figure 1). The conflict between Israel and Hezbollah posed a problem (or an opportunity) for the newly appointed Prodi government. For several reasons - the ongoing presence of Italian 
soldiers in the UNIFIL I mission, the enduring engagement with Lebanon through aid and development programs, and the likely implications of the war in the MENA region - the government concluded that an immediate reaction was needed in order to prevent the crisis from escalating and spreading to neighbouring countries. ${ }^{2}$ The regional effects of the crisis, the delicate balance of the Middle East, and Italy's mere lack of capabilities, however, called for a multilateral solution. This in turn raised a collective action problem: the international community was strongly interested in a quick solution to the conflict, but all members had an incentive to free ride. ${ }^{3}$ Conscious of this problem (the transatlantic crisis over Iraq being a lively reminder of the limits of multilateralism), the government faced a dilemma: either buckpassing or taking the lead.

\section{Figure 1 about here}

In order to make sense of the course of action undertaken by the Italian government in the summer of 2006, we need to take into account governmental interests. As one of the

\footnotetext{
${ }^{2}$ Therefore, the 2006 Israel-Hezbollah war was unique compared to other ongoing international crises where Italy was involved, including NATO's ISAF mission in Afghanistan and the coalition forces in Iraq. In fact, the multinational missions deployed in Afghanistan and Iraq followed a US led military involvement.

${ }^{3}$ This refers to collective action theory, developed in Mancur Olson's seminal book The Logic of Collective Action: Public Goods and the Theory of Groups, published in 1965. However, our analytical eclectic explanation differs from public good theory for two main reasons. Firstly, whilst Italy had a selective incentive to participate in UNIFIL II, this remains far from clear. Secondly, France was also an important contributor to the mission.
} 
main foreign policy priorities of the centre-left coalition was to differentiate itself to the previous centre-right government coalition, the war in Lebanon provided at least three opportunities:

a) to stress the virtues of multilateralism, allegedly discarded by the Berlusconi government's subjugation to the US;

b) to revive the EU as an international actor (in 2005 the Constitutional Treaty had stalled after France and the Netherland failed to ratify it);

c) to increase Italy's standing and reputation vis-à-vis the US and other major powers (Caffarena 2007, 160).

Coherently with the liberal argument, then, playing an active role in the solution of the war was perceived by the government as a governmental interest, as it would allow it to display coherence with its electoral manifesto as well as resolve in the eyes of public opinion and credibility vis-à-vis its allies (Pohl, van Willigen, and van Vonno 2016).

The lead-or-buckpass dilemma was then solved with a clear commitment towards the first option. The Italian engagement took the form of diplomatic activism, a course of action that would allow killing two birds with one stone: making multilateralism work, and increasing Italy's reputation as an honest broker. Firstly, with consultations at the G8 Summit. Secondly, by organizing the Rome Conference and pushing for enacting UN 
resolution 1701 (Calculli 2014). Finally, with the struggle to design a Strategic and Military Cell within the UN Department of Peacekeeping Operations (DKPO), ${ }^{4}$ Italy sought to raise its prestige by making it clear to the international community that it would carry the burden (and responsibility) of settling the issue (Coticchia and Moro 2015, 81). This behaviour is also in line with the liberal view, especially the neoliberal institutionalist view, according to which international organisations are tools that states use to reach their goals (Keohane 1984). However, one may argue, this is also consistent with the classical realist-inspired take on prestige: through its diplomatic and subsequently military commitment to ending the war, Italy was increasing its prestige in three critical areas. Firstly, it proved to be a worthy ally of the US. Secondly, it showed leadership as a member of the EU to revitalise the integration process. Thirdly, it proved to be an honest broker between the warring parties in the Middle East (Senato della Repubblica 2006).

Diplomatic activism ultimately led to military intervention. The idea of strengthening the ongoing peacekeeping mission appeared from the very beginning as the most viable (although not necessarily successful) solution. As a result, the main diplomatic concern for Italy was not just to forge consensus for a $\mathrm{UN}$ resolution, but also to assemble a strong enough military force to fulfil the demanding tasks laid out in the mandate of the

\footnotetext{
${ }^{4}$ We are indebted to Fabrizio Coticchia for bringing these considerations to our attention.
} 
resolution. Signalling Rome's commitment to deploy a significant amount of troops proved critical to overcome the collective action problem, but forced Italy to follow through on her promises. The decision to deploy troops in Lebanon had to be justified according to rationales that could be accepted across the political spectrum. Coherently with our model, the moral concern for the affected Lebanese population led to the humanitarian framing of the intervention.

The remainder of this article will assess the fit between the model and the case study based on a qualitative account of the Italian reaction to the war. Admittedly, being impossible to access classified documents and resort to in-depth interviews, we aim to provide a plausibility test of our model focused on publicly accessible data, namely the government's public declarations and the resulting parliamentary debate.

\section{Italy's choice to intervene in Lebanon}

How did Italy react to the 2006 conflict in Lebanon? Which foreign policy choices eventually led to the deployment of a 2500-strong contingent in the region? What rationale drove such behaviour? Did the drivers discussed above play any role in this calculation? To answer these questions, and to fully appreciate the complex decisions the Italian government took at the time, let us start by recalling Italy's political scenario. 
From a domestic perspective, the war in Lebanon occurred during an important time for Italian politics. The newly appointed Prime Minister Romano Prodi had taken office on the $17^{\text {th }}$ of May 2006 - i.e. less than two months before the war erupted - and was dependent on an unstable centre-left coalition. The broad coalition supporting the Prodi government, known as L'Unione (The Union), included as many as seven different parties covering the whole spectrum of the centre-left, from the former Cristian Democrats to the Greens and Communists. Nevertheless, the government could count on just a tiny majority (only ten seats) within the Upper Chamber of the Parliament (Senato della Repubblica 2006a).

In fact, the war in Lebanon resulted in a proving ground for the alleged U-turn in foreign policy that Prodi and his allies had trumpeted during the electoral campaign. As stressed clearly by Anna Caffarena (2007), regardless of all the possible sources of tension within the coalition, the centre-left had made it clear that an immediate goal of its foreign policy would be to take distance from the previous centre-right government, led by Silvio Berlusconi. Therefore, contrary to the purported subjection to the US dictates of the previous administration, Prodi would rather seek for 'a relationship of a different type loyal, but not subordinate - towards the United States' (Caffarena 2007, 156). Partnership with Europe would be chosen as 'the natural seat and multiplier of the effectiveness of 
the international political strategy of the country', and multilateralism (as embodied by the UN) would return as the guiding principle of Italy's international action (Caffarena 2007, 156). Finally, 'greater attention [would be] dedicated to the Mediterranean area to cultivate the historic siting of Italy' (D’Alema 2006).

Given these domestic constraints and opportunities, where did the Italian determination to play an active role in settling the conflict in Lebanon arise? In order to address this question, we will first describe the reaction of Prodi's government to the summer war between Israel and Lebanon: in particular, we will dwell upon the foreign policy initiatives launched since the end of July until Resolution 1701. After that, we will sum up the main themes discussed in the parliamentary debates on Lebanon from June to October 2006.

Italy's reaction to the war and foreign policy activism

The conflict between Israel and Hezbollah started on the $12^{\text {th }}$ of July 2006, after a Hezbollah-related group attacked a contingent of Israeli soldiers south of the so-called Blue Line, killing eight and kidnapping two. The Israeli Defence Force (IDF) reacted quickly, first by bombing Hezbollah's strongholds in various regions, then with sweeping sorties of the land forces in southern Lebanon. Hezbollah retaliated in turn, with a massive 
launch of missiles. Within a few weeks, the death toll had grown to the disturbing figure of about one thousand civilian casualties and one million displaced persons in Lebanon alone (Giunchi 2007; Makdisi 2009; Ronzitti 2007).

The international community reacted swiftly, as the conflict could quickly spread in the region and lead to the involvement of regional powers, such as Syria and Iran. As mentioned, such a quick reaction (epitomized by the peace conference on Lebanon, hosted in Rome on the $26^{\text {th }}$ of July 2006) was made possible by the diplomatic activism of a few countries, such as Italy and France.

It is worth stressing that Italy had been involved in Lebanon with a number of initiatives well before the war erupted. The most widely known is the military contribution to UNIFIL I, although the sheer number of troops at that time was in the order of fifty units. Other initiatives were aimed at promoting development through aid and donations (about 86 million Euros), mostly in the agricultural and water management sectors. When the war broke out, Italy provided Lebanon with emergency and humanitarian support worth about 1.35 million Euros. Moreover, 540.000 Euros were also destined to the war-torn regions via the World Health Organisation (WHO), the UN Office for the Coordination of Humanitarian affairs (OCHA) and the Parliamentary Assembly of the Mediterranean (PAM). Furthermore, 30 million Euros were allocated with the purpose of rebuilding the 
infrastructures damaged or destroyed by the war (Camera dei Deputati 2006; Camera dei Deputati 2006a).

However, the Italian involvement in the crisis was not limited to humanitarian assistance only. In fact, the diplomatic reaction displayed by the Prodi government showed a remarkable degree of foreign policy activism. Three main lines of action were pursued with the aim of leading the conflict resolution process: 1) in the conflict area, especially with Lebanon and Israel, 2) in multilateral fora, 3) at the EU level (Brighi 2013, 129). Whether these initiatives proved successful or not is beyond the scope of this article. Nor can we assess here if such activism eventually led to an increase in influence internationally. Our goal, in the following pages, is to understand Rome's goals and strategy. With this in mind, we will provide a concise overview of the main initiatives in chronological order.

In terms of activism in multilateral forums, Italy's first initiative came just a few days after the war erupted, at the G-8 Summit, held in St. Petersburg, Russia ( $15^{\text {th }}$ to the $17^{\text {th }}$ of July 2006). On that occasion, while recognising the need for peace and stability in the region, the major powers did not share a common view on how to stop the violence. For example, in a joint press conference on the $16^{\text {th }}$ of July 2006, US President George W Bush and UK Prime Minister Tony Blair blamed Hezbollah - implicitly defined as a 
terrorist organization - responsible for the war and openly expressed their support for Israel (the only cautionary note being that Israel's retaliation should be proportionate) (US Department of State 2006). On the contrary, Italy explicitly boasted its 'equinearness' with both Israel and Lebanon (Senato della Repubblica 2006, 13).

Different orientations forced the G-8 leaders to agree on a very general and open-handed statement: the wording of the document did not even spell out the term ceasefire, nor the idea of a peacekeeping mission. Conversely, the final statement called for the UN to intervene, with a view to implementing previous UNSC Resolutions 1559 and 1680 through an 'international security/monitoring presence' (US Department of State 2006a). From a diplomatic perspective, the problem was then two-fold: to gather consensus on the form the UN intervention should take (i.e. how to frame a new resolution), and to make sure that an eventual blue-helmets mission was operationally capable.

In order to tackle the first problem, in conjunction with the US, Italy hosted an international conference in Rome on the $26^{\text {th }}$ of June 2006. The Foreign Affairs Minister Massimo D'Alema, during his hearing at the joint committees on foreign affairs of the Senate and House of Representatives, outlined four main goals. These were a) to strengthen humanitarian action; b) to forge consensus on a UN mission to be deployed in Southern Lebanon; c) to persuade the international community to fund programs for the 
reconstruction and stability of Lebanon and d) discuss the conditions for a ceasefire (Senato della Repubblica 2006, 6). The second and fourth points were obviously interrelated, as they had to do with the possibility for Israel to accept foreign military forces at its borders - a critical step to deploy the UN-mandated mission. The main division among the parties was between those, such as Italy and France, who called for an immediate ceasefire, to be followed by negotiations on how to intervene and address the deep causes of the conflict. Conversely, other parties (such as the US and Israel) required to negotiate the terms of the ceasefire to ensure that Hezbollah could not take advantage of the ceasefire. Consequently, the conference did not bridge the distance between the two competing views. It only found the diplomatic lowest common denominator by urging Israel and Hezbollah 'to reach with the utmost urgency a ceasefire [...] that must be lasting, permanent and sustainable' and calling for a UN intervention, so setting the stage for the upcoming UN Security Council Resolution 1701 (International Conference on Lebanon 2006).

Nevertheless, an agreement was eventually reached, on the $11^{\text {th }}$ of August 2006, with UN resolution 1701. The UN called for a truce among the parties and upgraded the existing UNIFIL mission (dating back to 1978) strengthening the 2000-strong contingent already deployed with up to additional 13000 soldiers (IISS 2007). From the very beginning, then, the UN forces were given a variety of tasks that qualified the operation most properly as 
robust peacekeeping. In fact, the range of tasks spanned from 'ensur[ing] humanitarian access to civilian populations and the voluntary and safe return of displaced persons' which is clearly a civilian task - to 'Monitor[ing] the cessation of hostilities' and 'support[ing] the Lebanese armed forces as they deploy throughout the South, including along the Blue Line, as Israel withdraws its armed forces from Lebanon' - the most traditional peacekeeping function (United Nations 2006). Beyond that, the Resolution also called for the multinational force to support the Lebanese army in the attempt to reestablish control over southern regions of Lebanon.

Admittedly, Italy's role in promoting UN resolution 1701 is debatable. In fact, after the Rome Conference, Prodi and D'Alema operated (with little success) at the GAERC meeting on the $1^{\text {st }}$ of August and through bilateral consultations with the warring parties. Arguably, not being a member of the Security Council at the time, Italy's capability to affect negotiations and have an impact on the text of the resolution were limited. ${ }^{5}$ In fact, the France-US tandem set the tone of the diplomatic bargain (Engberg 2010). One of the most contentious issues was the leadership of the military mission to be deployed in Lebanon, with the UN and NATO being the main available options (Podrazik 2007).

\footnotetext{
${ }^{5}$ Incidentally, Italy was campaigning for a non-permanent seat at the UN Security Council at the time of the crisis. For an in-depth analysis see Salleo and Pirozzi (2008).
} 
This stalemate was eventually overcome by a US-France agreement, which was reached at the beginning of August 2006. France and the US issued a draft resolution (that later became the nucleus of Resolution 1701) in which they convened to call for 'a full cessation of hostilities based upon, in particular, the immediate cessation by Hezbollah of all attacks and the immediate cessation by Israel of all offensive military operations' (Engberg 2010: 422). The UN mandate for a renewed UNIFIL mission, however, required an immediate military commitment. Those who favoured this solution to the war were now asked to carry the burden of sending their troops in an all-but-easy situation. In other words, a typical collective action problem.

To overcome this obstacle, Italy tried to compensate the risk that other powers might fail to provide the necessary troops. ${ }^{6}$ It did so by signalling its commitment to deploy military forces from the beginning. Prodi released public statements following the G-8 summit and D'Alema reiterated the Italian willingness to deploy a considerable military contingent in his opening speech at the conference (Marozzi 2006). In practical terms, since mid-July, Italy deployed a humanitarian operation (Operation Mimosa) and an (Interim) Maritime Task Force (Marta 2009). For a variety of reasons, Italy had to

\footnotetext{
${ }^{6}$ The main example of this problem was France: as illustrated by Katarina Engberg (2010: 419), French President Jacques Chirac had initially offered as many as 3,000 units for the peacekeeping mission, but its commitment soon appeared to waver. Likewise, Germany was initially reluctant to be involved in a theatre so close to Israel.
} 
negotiate with France the terms of their burden sharing. ${ }^{7}$ In fact, by the end of August it was agreed that Italy would contribute about 3,000 out of the planned 10,000 European units (The Economist 2006). However, in the end approximately 2,500 Italian soldiers were actually deployed according to the data made available by the Italian Ministry of Defence (Ministero della Difesa 2007). Furthermore, Rome would take over the command of the mission at the end of the French term, in February 2007.

\section{The parliamentary debate}

The Italian Parliament closely followed the events in Lebanon and the government's reaction. In the present analysis, we have taken into account all the available parliamentary acts from the outbreak of the hostilities up to the ratification of the military intervention - i.e. the period from July to October 2006. Both Chambers have discussed at length the ongoing operations in the years that followed, mostly with a view to confirming the financing of the mission with ad hoc laws, but we find the parliamentary debate in this case to be quite shallow. On the contrary, the positions expressed by the members of both Chambers of the Parliament in the wake of the war provide an exhaustive picture of the rationale driving the Italian involvement in the conflict.

\footnotetext{
${ }^{7}$ France played a key role in leading the negotiations within the UN Security Council; furthermore, UNIFIL I was under the French command.
} 
As discussed by Fabrizio Coticchia in his analysis of parliamentary acts and government communication, the political discourses of both the executive and legislative bodies justify the rationale for the Italian involvement in Lebanon in terms of promoting peace and stability (Ignazi, Giacomello, and Coticchia 2011, 78-80). At a minimum, especially in the early weeks following the UN resolution, many MPs and government officials portrayed the mission as the only way to make the ceasefire work (Camera dei Deputati 2006c, 34, 44; Senato della Repubblica 2006c, 32; Senato della Repubblica 2006d). A more ambitious, but still realistic, view held that the peacekeeping mission could halt the hostilities and set the foundations for a stable border between Israel and Lebanon (Camera dei Deputati 2006c; Senato della Repubblica 2006c, 67). Finally, some even argued that - by virtue of its international legitimacy - UNIFIL II could contribute to the stabilization of the whole of the Middle East (Camera dei Deputati 2006a; Senato della Repubblica 2006b).

Senator Roberta Pinotti (Ulivo), then president of the IV Committee - Armed Forces and later Minister of Defence, expressed the most vocal pledge to the intervention based on moral grounds, on the $6^{\text {th }}$ of September. Her point was entirely based on moral grounds: as she claimed, the high stakes of the war in terms of human security made it a moral obligation for Italy to do whatever possible to prevent the conflict from further escalation 
or spill over. In her intervention, she underscored how the war could trigger a regional crisis whose effects could endanger peace on a global scale. In her own words, 'The mission [...] will be long, demanding, costly and risky. But it is just and necessary and for this reason it must be supported' (Camera dei Deputati 2006a). Therefore, as the constructivist view would hold, it is safe to say that the political discourse was influenced by a humanitarian framing of the mission.

However, the humanitarian concern is hardly enough on its own to explain the Italian involvement in the mission. Coherently with our model, in his analysis Coticchia finds that the parliamentary debate most frequently referred to multilateralism as a main driver of action. This is due to the continuous references to the UN resolution 1701, but also to the self-professed role that Rome was playing in gathering a coalition of allies (Ignazi, Giacomello, and Coticchia 2011, 78). For example, in his opening statement at the joint session of the Defense and Foreign Affairs committees on the $9^{\text {th }}$ of September MP Umberto Ranieri claimed that the resolution was ultimately the result of the Italian (and French) leadership in Europe. According to Ranieri 'the Italian government deserves credit because, with its enduring willingness, it kept open to the option of a peacekeeping mission with a strong European flavour, even when the French reluctance to intervene risked to sink the whole project' (Camera dei Deputati 2006, 4). 
The emphasis on multilateralism is therefore critical to explain the Italian reaction to the 2006 war: the government's pledge to a multilateral framework for intervention allowed the Parliament to reach bipartisan consensus and avoid a majority-opposition stalemate. In fact, while the representatives of the opposition parties endorsed a different vision of multilateralism (i.e. a Western-based, US-led vision as opposed to the government's EUbased conception), ${ }^{8}$ only the Lega Nord voted against the intervention; Forza Italia (FI), Alleanza Nazionale (AN) and Unione di Centro (UDC) did not raise any objection of substance to the DL 253/06, claiming in turn their sense of responsibility (Camera dei Deputati 2006c; Senato della Repubblica 2006c).

Finally, the multilateral approach pursued by the government was functional to a complementary goal, which was to raise the country's status and prestige. In this vein, the Italian involvement in Lebanon can be understood as a way to bolster its leading role within the EU in particular, and in the West in general. However, the parliamentary debate shows mixed evidence of this. The aim to increase Italy's prestige is explicitly ruled out by Senator Pinotti in the same speech quoted above. In her own words: 'it would be incorrect, and also slightly cynical, to think that all this has been made [...] for the need to claim its presence on the international stage' (Camera dei Deputati 2006a, 6). In the

\footnotetext{
${ }^{8}$ See, for instance, Gianfranco Fini's and Pier Ferdinando Casini's statements in Camera dei Deputati, 2006a: p. 16.
} 
same vein, Sergio Mattarella (the current President of the Republic), claimed that the mission was not just a matter of Italian prestige, but most properly, a problem of international solidarity towards the populations involved in the conflict (Camera dei Deputati 2006a, 17).

On the other hand, other figures (both among majority and among opposition parties) highlighted the prestige (purportedly) gained by the country because of its activism in the conflict. For instance, MP Pasqualino Giuditta emphatically claimed that Italy played a "prestigious international role [...] so bolstering the image of the country in foreign policy" (Camera dei Deputati 2006c, 70). Likewise, in a Senate debate on October 17, 2006, Senator De Gregorio praised the Foreign Affairs Minister for his diplomatic efforts, so 'making Italy the leading figure in the peace process among the parties, something that raises our prestige in the role of peace building' (Senato della Repubblica 2006a, 13). By reverse, argued centre-right Senator Antonione, had Italy failed to send troops, this would have undermined Italy's credibility and prestige (Senato della Repubblica 2006a, 53). Eventually, the most explicit supporter of prestige as a key interest of the country was Senator Polito, who openly stated that 'increasing Italy's prestige (autorevolezza) and weight in the future decisions of the international community [is] highly valuable for the national interest' (Senato della Repubblica 2006b, 27). Therefore, it seems safe to 
conclude that the issue of prestige entered the parliamentary debate, but it did not enjoy a widely shared recognition as a rationale for the intervention.

\section{Conclusion}

For Italy, participating in the UNIFIL II mission was a demanding and risky task. In the absence of a direct threat and a clear strategic interest, we were interested in investigating how single, competing drivers could interact and contribute to an analytical eclectic explanation. In comparison to previous theoretically informed contributions on Italian foreign policy, we presented an analytical eclectic model of military intervention in multilateral operations which blends prestige, governmental interest and humanitarian concern coherently and which, in our view, holds more explanatory power.

Governmental interest, prestige and humanitarian concern all conflated into the Italian government's decision to get involved in the crisis. In particular, we have argued that the Prodi government's interest in multilateralism made Italy's peculiar reaction to the war in Lebanon possible. A governmental goal maximized the unity of the coalition. It also provided a point of departure from the previous Berlusconi administration and allowed Italy to obtain international legitimacy. At the same time, the government sought to increase its international prestige in at least two ways. Firstly, by leading diplomatic 
negotiations and carrying a significant share of the burden, it proved aware of the limits of multilateralism. Secondly, despite the fact that the Prodi government denied any deliberate attempt to pursue anything of the sort of a national interest, it also tried to increase the Italian standing and influence in international institutions. Finally, the constructivist focus on culture and norms allows us to make sense of the narrative that informed the parliamentary debate and the overall conception of Italy's role in Lebanon.

To conclude, this work presented a single case study for the purpose of a plausibility test of the model that we introduced. We are aware of the limits of the eclectic approach we have used here - most significantly, the narrow focus on just three causal factors. However, we believe that the model sheds light on the foreign policy drivers of middle powers. As such, it could be applied to other middle powers to make sense of their contribution to military missions absent clear interests in doing so. Furthermore, as concerns the Italian case, a more detailed account of the decision making that led to the intervention could be made through process tracing: a detailed account of the key governmental players and their role in the lead-up to the deployment of UNIFIL II will probably shed light on the motives and intentions underlying this choice. Moving beyond Italy, the broader question concerns whether the mechanism displayed in the previous paragraph is also at play in other countries; and, if not, what are the conditions that must 
be met to make it work elsewhere? As a result, in the future our findings could be tested by using different case studies or by carrying out comparative analyses.

\section{Funding}

The research received no grants from public, commercial or non-profit funding agency.

\section{Acknowledgements}

An earlier version of this article was presented at the European Consortium for Political Research (ECPR) General Conference in Prague in September 2016. We thank the anonymous reviewers for their careful reading of our manuscript and their insightful comments and suggestions. We would also like to thank Fabrizio Coticchia, Nicole Scicluna, Julian Paenke and George Kyris for their helpful and constructive comments on a previous version of this article. We also gratefully acknowledge Emma Cladi for her patient editorial assistance. The usual disclaimer applies.

\section{References}

Andreatta, Filippo. 2008. 'Italian Foreign Policy: Domestic Politics, International Requirements and the European Dimension', Journal of European Integration, 30(1), pp. $169-181$. 
Andreatta, Filippo. 2001. 'Italy at the Crossroads: The Foreign Policy of a Medium Power after the End of Bipolarism'. Daedalus 130(2): 45-65.

Brighi, Elisabetta. 2013. Foreign policy, domestic politics and international relations: the case of Italy. London: Routledge.

Caffarena, Anna. 2007. 'The Israeli-Lebanese War: Italy and the Recasting of an Effective Multilateralism'. In Italian Politics. The Center-Left's Poisoned Victory, edited by Jean-Louis Briquet and Alfio Mastropaolo, 154-171. New York: Berghahn Books. Calculli, M. (2014) 'National prerogatives in multilateral peacekeeping: Italy in Lebanese perception and Rome's role within UNIFIL II', Cahiers de la Méditerranée 88: 1-15. Camera dei Deputati. 2006. 'III Commissione Permanente (affari esteri e comunitari), Interrogazioni a risposta immediata', 28 July.

Camera dei Deputati. 2006a. 'Commissioni Riunite III (Affari esteri e comunitari) e IV (Difesa), DL 253/06: Partecipazione italiana alla missione in Libano, 6 September. Camera dei Deputati. 2006c. 'XV Legislatura, Assemblea, 41a seduta pubblica', 25 September.

Carati, Andrea and Andrea Locatelli. 2017. 'Cui prodest? Italy's questionable involvement in multilateral operations amid ethical concerns and national interest', International Peacekeeping 24 (1): 86-107. 
Carati, Andrea and Andrea Locatelli. 2015. 'Ticket to ride: Italy's participation to multilateral missions and the preservation of its international status', paper presented at the BISA Annual Conference, London, June 17.

Ceccorulli, Michela and Fabrizio Coticchia. 2017. 'Stick to the plan? Culture, interests, multidimensional threats, and Italian defence policy'. Italian Political Science Review 47 (2): 183-203.

Ceccorulli, Michela and Fabrizio Coticchia. 2015. 'Multidimensional Threats and Military Engagement: The Case of the Italian Intervention in Libya', Mediterranean Politics 20 (2): 303-21.

Cladi, Lorenzo and Mark Webber. 2011. 'Italian foreign policy in the post-Cold War period: a neoclassical realist approach'. European Security 20 (2): 205-219.

Coticchia, Fabrizio and Giampiero Giacomello. 2008. 'Esiste una Via Italiana alla Cultura di Difesa?', Biblioteca della Libertà XLIII 193: 109-122.

Coticchia, Fabrizio and Francesco Moro. 2015. Adapt, improvise, overcome? The transformation of Italian Armed Forces in comparative perspective. Abindgon: Routledge.

D’Alema, Massimo. 2006. 'La politica estera dell'Italia'. Affari esteri 38 (151): 460-462. Davidson, Jason W. 2013. 'France, Britain and the intervention in Libya: an integrated analysis'. Cambridge Review of International Affairs 26 (2): 310-329. 
Davidson, Jason W. 2009. 'Italy-U.S. relations since the end of the Cold War: prestige, peace, and the transatlantic balance'. Bulletin of Italian Politics 1 (2): 289-238.

Engberg, Katarina. 2010. 'To Intervene or Not to Intervene? The EU and the Military Option in the Lebanon War of 2006'. Perspectives on European Politics and Society 11 (4): 408-428.

Finnemore, Martha. 1996. 'Constructing Norms of Humanitarian Intervention'. In The Culture of National Security: Norms and Identity, edited by Peter J. Katzenstein, 153185. New York: Columbia University Press.

Freedman, Lawrence. 1976. 'Logic, Politics and Foreign Policy Processes: A Critique of the Bureaucratic Politics Model'. International Affairs 52 (3): 434-49.

Gegout, Catherine. 2009. 'The West, Realism and Intervention in the Democratic Republic of Congo (1996-2006)'. International Peacekeeping 16 (2): 231-244.

Gilpin, Robert. 1981. War and Change in World Politics. Cambridge: Cambridge University Press.

Giunchi, Elisa. 2007. 'La guerra in Libano'. In L'Italia e la politica internazionale, edited by Alessandro Colombo and Natalino Ronzitti, 67-80. Bologna: Il Mulino.

Harnish, Sebastian. 2001. 'Change and Continuity in Post-Unification German Foreign Policy', German Politics 10 (1): 35-60.

Hudson, Kate. 2012. The New European Left: A Socialism for the Twenty-First Century. Houndmills, Basingstoke: Palgrave Macmillan. 
Ignazi, Piero, Giampiero Giacomello, and Fabrizio Coticchia. 2011. Italian military operations abroad: just don't call it war. London: Palgrave Macmillan.

International Conference on Lebanon. 2006. 'Co-Chairmen Statement', Rome, 26 July, available at: http://www.state.gov/documents/organization/98981.pdf.

Isernia, Pierangelo, and Francesca Longo. 2017. 'The Italian foreign policy: challenges and continuities'. Italian Political Science Review 47 (2): 107-124.

Johnston, Alastair Iain. 1995. Cultural Realism: Strategic Culture and Grand Strategy in Chinese History. Princeton, NJ: Princeton University Press.

Kaarbo, Juliet. 1996. 'Power and Influence in Foreign Policy Decision-Making: The Role of Junior Coalition Partners in German and Israeli Foreign Policy', International Studies Quarterly 40 (4): 501-30.

Katzenstein, Peter J., ed. 1996. The Culture of National Security. New York: Columbia University Press.

Keohane, Robert. 1984. After Hegemony: Cooperation and Discord in the World Political Economy. Princeton: Princeton University Press.

Knudsen, Tony Brems. 2013. 'The responsibility to protect: European contributions in a changing world order'. In The European Union and International Institutions: Performance, Policy, Power, edited by Knud Erik Jørgensen, and Katie Verlin Laatikainen, 157-70, Abingdon: Routledge. 
Larson, Deborah W. and Shevchenko Alexei. 2010. 'Status Seekers. Chinese and Russian Responses to U.S. Primacy', International Security, 34 (4): 63-95.

Legro, Jeffrey W. 2005. Rethinking the World: Great Power Strategies and International Order. Ithaca NY: Cornell University Press.

Makdisi, Karim. 2011. 'Constructing Security Council Resolution 1701 for Lebanon in the Shadow of the 'War on Terror'. International Peacekeeping 18 (1): 4-20.

Makdisi, Karim, et al. 2009. 'UNIFIL II: Emerging and Evolving European Engagement in Lebanon and the Middle East', EUROMERSCO Paper No. 76, January. Available at: http://www.euromesco.net/images/paper76eng.pdf.

Markey, Daniel. 1999. 'Prestige and the Origins of War: Returning to Realism's Roots', Security Studies 8 (4): 126-73.

Marozzi, Marco. 2006. 'Prodi: pronti a participate a una forza di pace in Libano'. La Repubblica 18 July.

Marsh, David. 2008. 'Understanding British Government: Analysing Competing Models'. British Journal of Politics and International Relations 10 (2): 251-268.

Marta, Lucia. 2009. 'The UNIFIL Mission in Lebanon: Italy's Contribution'. Security and Defence - ARI paper no. 125. Available at: http://www.realinstitutoelcano.org/wps/portal/web/rielcano_en/contenido?WCM_GLO

BAL_CONTEXT=/elcano/elcano_in/zonas_in/defense+security/ari125-2009. 
Ministero della Difesa. 2007. 'Nota aggiuntiva allo stato di previsione per la Difesa per

l'anno 2007'. Available at:

http://www.difesa.it/Content/Documents/nota_aggiuntiva/86808_NotaAggiuntiva2007.

pdf.

Morgenthau, Hans J. 1985. Politics Among Nations. $6^{\text {th }}$ ed. New York: Knopf.

Olmastroni, Francesco. 2014. 'Patterns of isolationism: a quantitative assessment of Italy's defence and foreign policy from government alternation to 'grand coalitions'. Contemporary Italian Politics 6:3: 285-299.

Panke, Diana, and Thomas Risse. 2007. 'Liberalism'. In International Relations Theories: Discipline and Diversity, edited by Tim Dunne, Milja Kurki, and Steve Smith, 90-107, Oxford: Oxford University Press.

Pirani, Pietro. 2010. 'The Way We Were': the Social Construction of the Italian Defence Policy’. Modern Italy 15 (2): 217-230.

Podrazik, Patrycja. 2007. 'Reluctant to Lead: The Lebanese Conflict and the EU's Common Security Policy', Yale Journal of International Affairs 2 (2): 4-16.

Pohl, Benjamin, Niels van Willigen, and Cynthia van Vonno. 2016. 'Governmental interest, new Liberalism and the CSDP'. In International Relations Theory and European Security: We Thought We Knew, edited by Lorenzo Cladi and Andrea Locatelli, 65-83, Abingdon: Routledge. 
Ratti, Luca. 2012. 'All Aboard the Banwagon? Structural Realism and Italy's International Role'. Diplomacy and Statecraft 23 (1): 87-109.

Renshon, Jonathan. 2017. Fighting for Status: Hierarchy and Conflict in World Politics Princeton NJ: Princeton University Press.

Robinson, Piers. 2001. 'Theorising the Influence of Media on World Politics: Models of Media Influence on Foreign Policy'. European Journal of Communication 16 (4): 523544.

Romano, Sergio. 2009. 'Italian foreign policy after the end of the cold war', Journal of Modern Italian studies, 14 (1): 8-14.

Romero, Federico. 2016. 'Rethinking Italy's Shrinking Place in the International Arena', The International Spectator, 51 (1): 1-12

Ronzitti, Natalino. 2007. 'L'UNIFIL II in Libano: un bilancio della presenza italiana', Affari Internazionali 10 December Available at: http://www.affarinternazionali.it/articolo.asp?ID=683.

Salleo, Ferdinando and Nicoletta Pirozzi. 2008. 'Italy and the United Nations Security Council'. The International Spectator 43 (2): 95-111.

Santoro, Carlo M. 1991. La Politica Estera di una Media Potenza. L'Italia dall'Unità ad Oggi. Bologna: Il Mulino.

Senato della Repubblica. 2006. 'XV Legislatura, Commissioni Congiunte 3a (Affari esteri, emigrazione) del Senato della Repubblica e III (Affari esteri e comunitari) della 
Camera dei deputati, Audizione del Ministro degli Affari Esteri sugli sviluppi della situazione in Medio Oriente', 27 July. Available at: http://www.senato.it/japp/bgt/showdoc/frame.jsp?tipodoc=SommComm\&leg=15\&id=2 15720.

Senato della Repubblica. 2006a. 'XV Legislatura, Assemblea, 6a seduta pubblica', 19 May. Available at: http://www.senato.it/service/PDF/PDFServer/BGT/00208760.pdf. Senato della Repubblica. 2006c. 'XV Legislatura, Assemblea, 54a seduta pubblica', 17 October. Available at: http://www.senato.it/service/PDF/PDFServer/BGT/220628.pdf. Senato della Repubblica. 2006d. 'XV Legislatura, Assemblea, 55a seduta pubblica', 17 October. Available at: http://www.senato.it/service/PDF/PDFServer/BGT/220869.pdf. Sil, Rudra, and Katzenstein, Peter J. (2010) Beyond Paradigms: Analytic Eclecticism in the Study of World Politics. Basingstoke: Palgrave Macmillan.

Smith, Craig S. 2008. 'Europe Pledges a Larger Force Inside Lebanon’. New York Times, 26 August.

Sørensen, Georg. 2008. 'The Case for Combining Material Forces and Ideas in the Study of IR'. European Journal of International Relations 14 (1): 5-32.

Tercovich, Giulia. 2016. 'Italy and UN peacekeeping: constant transformation', International Peacekeeping 23 (5): 681-701.

The Economist. 2006. 'Taking Shape: Italy Is Ready to Lead a UN Peacekeeping Force in Lebanon, with France Taking Only a Secondary Role', 23 August. 
Thies, Cameron G., and Marijke Breuning. 2012. 'Integrating Foreign Policy Analysis and International Relations through Role Theory'. Foreign Policy Analysis 8 (1): 1-4. United Nations. 2006. 'Security Council calls for end to hostilities between Hizbollah, Israel, unanimously adopting resolution 1701'. New York, 11 August. Available at: http://www.un.org/press/en/2006/sc8808.doc.htm.

US Department of State. 2006. 'President Bush and British Prime Minister Blair Discuss the Middle East, Iraq, and Iran During Meeting'. Cottage Nine, Konstantinovsky Palace Complex Strelna, Russia, 16 July. Available at: http://20012009.state.gov/p/eur/rls/rm/69051.htm.

US Department of State. 2006a. 'Statement by Group of Eight Leaders', G8 Summit, St. Petersburg, 16 July. Available at: https://2001-2009.state.gov/p/eur/rls/prsrl/69054.htm. Valigi, Marco. 2010. 'Il comportamento delle medie potenze in ambiente anarchico: un modello'. Quaderni di Scienza Politica 17 (1): 163-204.

Vanhoonacker, Sophie, Hylke Dijkstra, and Heidi Maurer. 2010. 'Understanding the Role of Bureaucracy in the European Security and Defence Policy: the State of the Art'. European Integration Online Papers, 14 (1): 1-33.

Volgy, Thomas et al. (eds.). 2011. Major Powers and the Quest for Status in International Politics. New York: Palgrave-MacMillan.

Waltson, James. 2007. 'Italian Foreign Policy in the "Second Republic": Changes in form and substance', Modern Italy, 12 (1): 91-104. 
Wood, Steve. 2013. 'Prestige in World Politics: History, Theory, Expression'. International Politics 50 (3): 387-411. 